\title{
Stewardship and Renewal of Catholic Places of Worship in Australia
}

\author{
La administración y la renovación de los lugares de culto católico en Australia
}

Ursula de Jong · Deakin University (Geelong, Australia), ursula.dejong2020@gmail.com

Flavia Marcello·Swinburne University (Melbourne, Australia), fmarcello@swin.edu.au

Recibido: $31 / 07 / 2019$

Aceptado: 04/02/2020

(cc) BY-NC https://doi.org/10.17979/aarc.2019.6.0.6236

\begin{abstract}
The National Liturgical Architecture and Art Council (NLAAC) is an advisory body to the Bishops' Commission for Liturgy of the Australian Catholic Bishops Conference, mandated to provide advice in the areas of liturgical architecture, art and heritage. The Council has prepared guidelines for use throughout the Catholic Church in Australia. The most recent of these documents, Fit for Sacred Use: Stewardship and Renewal of Places of Worship (2018) focusses on existing church buildings with particular reference to cultural heritage, and is the subject of this paper. Vatican II sought the full and active liturgical participation of all the people and so existing churches were reordered to foster inclusion. It is timely to consider questions around what constitutes our heritage and how it is valued. Fit for Sacred Use sets out the liturgical and heritage principles which are fundamental to conserving, renovating and reordering a church building. Its holistic approach considers how we renew our churches while honouring our heritage.
\end{abstract}

\section{KEYWORDS}

Catholic Churches in Australia, Cultural Heritage, Guidelines for Care and Protection, Vatican Council II, Liturgy

\section{RESUMEN}

El Consejo Nacional de Arquitectura y Arte Litúrgico (NLAAC) es un órgano asesor de la Comisión Episcopal de Liturgia de la Conferencia de Obispos Católicos de Australia, con el mandato de brindar asesoramiento en las áreas de arquitectura litúrgica, arte y patrimonio. El Consejo ha preparado pautas para su uso en toda la Iglesia Católica en Australia. El más reciente de estos documentos, Fit for Sacred Use: Stewardship and Renewal of Places of Worship (2018) se centra en los edificios eclesiales existentes con referencia particular al patrimonio cultural, que es el tema de esta ponencia. El Vaticano II buscó la participación litúrgica, plena y activa, de todas las personas, por lo que las iglesias existentes se reordenaron para fomentar la inclusión. Es oportuno considerar preguntas sobre lo que constituye nuestro patrimonio y cómo se valora. Fit for Sacred Use establece los principios litúrgicos y patrimoniales que son fundamentales para conservar, renovar y reordenar un edificio de la iglesia. Su enfoque holístico considera cómo renovamos nuestras iglesias mientras honramos nuestra herencia.

\section{PALABRAS CLAVE}

Iglesias católicas en Australia, patrimonio cultural, pautas de cuidado y protección, Concilio Vaticano II, liturgia

Cómo CITAR: De Jong, Ursula and Flavia Marcello. 2019. «Stewardship and renewal of catholic places of worship in Australia». Actas de Arquitectura Religiosa Contemporánea 6: 156-171. https://doi.org/10.17979/aarc.2019.6.0.6236. 


\section{INTRODUCTION}

This paper reflects on the footprint left by the renewal of the Catholic liturgy after the Second Vatican Council in Australia, through new guidelines set out by Australia's National Liturgical Architecture and Art Council (NLAAC). While their publication Fit for Sacred Use (2018) deliberately does not discuss any examples, or provide any illustrations, this paper considers a small number of cathedrals and churches in Australia in order to better understand the complexities of stewardship and renewal. In this way it frames critical issues in theory and in practice relating to how the heritage values of a church are determined. Churches are an excellent example of what Henri Lefebvre calls representational space (1991). A church is directly lived through a set of associated images and symbols. While it is dominated by ideology, it is experienced through the enactment of liturgy and the space, that is both produced by it and determines it.

While the global Catholic Church itself has a long association with the arts, as patron as well as custodian, and a documented intent to preserve this heritage through centuries, in Australia we are confronted with a chequered history in relation to our built ecclesiastical heritage. In the 21 st century we are now asking what have we gained, as well as what have we lost over the past five decades, and are seeking another way to identify, document, protect, conserve and valorise the cultural patrimony of the Church in Australia.

The NLAAC is an advisory body to the Bishops' Commission for Liturgy of the Australian Catholic Bishops' Conference. It is mandated to provide advice in the areas of liturgical architecture, art and heritage. One approach adopted by the Council for providing advice has been the preparation of documents in the form of guidelines for use throughout the Catholic Church in Australia. The most recent of these documents, Fit for Sacred Use: Stewardship and Renewal of Places of Worship, was approved by the Australian Catholic Bishops' Conference in November 2018 and published soon after. It is the subject of this paper. Fit for Sacred Use is the companion volume to And when churches are to be built... Preparation, planning and construction of places of worship (2015). Whereas the latter focusses on new church buildings, Fit for Sacred Use focusses on existing church buildings, with particular reference to cultural heritage.

Change and evolution are part of the lived-life of the church. Existing churches stem from many stylistic and cultural traditions and yet each had to adapt their liturgical space to the new thinking. The second Vatican Council sought the full and active participation of all the people. As a result, existing churches were reordered and new churches were designed with new spatial considerations to foster inclusion. The haste to implement change had three main impacts: misunderstandings of the required changes leading to an attitude of «in with the new, out with the old», a lack of respect for tradition, and a loss of heritage. Five decades on, with new guidelines to hand, it is timely to revisit some of the discussions and consider questions around what constitutes our heritage. And further, to acknowledge that a church may be valued, seen and experienced differently depending on the perspectives of a faith community, church history, architectural history, urban history and social history. Like an urban square gathers crowds and markets gather products (and buyers) (Lefebvre 1991) so does the post-Vatican church gather communities of the faithful. Vatican II effectively brought about a return to the church as a social space as an outcome of a process with many aspects and many currents, perceived and experienced, practical and theoretical (Lefebvre 1991).

Literally heritage means that which we have inherited, encompassing the tangible and intangible. Cultural heritage speaks about place, history, identity and memory. Moreover, forms of heritage can be at odds with one another: preservation of some layers may impede the conservation of others, restoring some features may not allow for the adaptation of others. Churches are used for liturgical celebrations and evangelisation but continue to play a significant role in defining identity, as well as building and maintaining community. They are significant places, sacred places where the parish community gathers to encounter God, through the word, the eucharist and the people, who are the body of Christ. Continuity of 
use allows the community to respect the associations and meanings of the church building. Culture, however, is more than what we have inherited from the past; it is a living, dynamic and participatory present reality. Fit for Sacred Use sets out the liturgical and heritage principles fundamental to conserving, renovating and reordering a church building. The holistic approach of Fit for Sacred Use considers how we renew our churches while honouring our heritage and maintaining contact with the community.

\section{FIT FOR SACRED USE}

Mark Coleridge in introducing Fit for Sacred Use (FFSU), notes that it «sets out the liturgical and heritage principles that are foundational for conserving, renovating and reordering a church building». And that «It elaborates the standards to be observed in exercising proper stewardship for a church building» (FFSU, Foreword). The Catholic liturgy required particular spatial arrangements, which predicated the sequence of gestures and movements. From the early years of European settlement, these traditions were handed down, and built on Australian soil (for example St Patrick's Cathedral, Melbourne). Given the locations of doors, columns and pews, the congregation knew where to enter, where to walk, where to sit. Stepped areas, richer materials, screens and pulpits indicated sacred spaces and as well as areas reserved for the clergy, who were most closely connected to God.

This post-Tridentine model depended on strict hierarchies and demarcations. In the celebration of the Mass the priest faced away from the congregation and towards the altar, he was placed closer to heaven, communing with God in Latin on behalf of the congregation (Fig. 04). Vatican II changed all that. To include the faithful and to open the Church to the outside world, the priest now faced the congregation, and using the vernacular language, the priest and the assembled together celebrate the Eucharist (Fig. 05) (de Jong and Marcello 2018). The spatial arrangement of the church that was set down by pre-Vatican II liturgical practice no longer fitted - what the space told the people to do and what they were supposed to do were now at odds with each other.
The title, Fit for Sacred Use, derives from Sacrosanctum Concilium 122, the Constitution on the Sacred Liturgy from the Second Vatican Ecumenical Council. There the Council fathers exhorted:

Holy Mother the Church has always been the friend of the fine arts and has ever sought their noble help, with the special aim that all things set apart for use in divine worship should be truly worthy, becoming, and beautiful, signs and symbols of the supernatural world (...) and thereby fitted for sacred use. (FFSU, Preface)

This is vital in the care of churches and in their adaptation.

Patrick O'Regan argues in the introduction, that

both the liturgy and the buildings erected for its celebration are sacramental - the liturgy explicitly in symbolism and celebration, the liturgical setting implicitly in its signification and ordering». And further, that «the chapels, churches and cathedrals in which the liturgy is celebrated are bearers of the tangible fabric of cultural heritage, in their architectural form and detail, type of construction, and materials. (FFSU, Introduction)

Fit for Sacred Use demonstrates a maturing and a rethinking of heritage in relation to the Catholic church in Australia. As O'Regan states, it

is steeped in the traditions of Catholic liturgy and patrimony, and in the precepts of international and Australian heritage standards. It provides a comprehensive framework for caring for the fabric of places of worship, together with clear guidance for renewing church buildings. It further offers practical information to assist those who will be responsible for the stewardship and renewal of places of worship. (FFSU, Introduction)

Fit for Sacred Use is ordered in three parts: 1. Unearthing the foundations; 2. Renewing the church and 3. Honouring our heritage. Part 1 considers liturgical and heritage principles. Part 2 considers the Church in its setting, as a whole and in all its parts, in a practical way. Part 3 considers the language of heritage, through its ideas and words, who is involved and the heritage process itself. Fit for Sacred Use is intended for use by all those who may 
be involved in caring for and renewing a church, including bishops, parish priests, architects, artists, heritage experts, conservators, liturgists, parish and other Church communities and their building committees, Heritage Councils and officers, diocesan Liturgical Commissions and diocesan Commissions of Sacred Art and Architecture, and educators. Each part of Fit for Sacred Use employs excerpts from documents of the second Vatican Council, passages of scripture and Church publications designated as living heritage, and establishes guiding principles. For the first time church documents and secular documents sit side by side to inform thinking, decisions and practice.

For the Catholic church, the Second Vatican Council of 1962-65 marked a period of spiritual renewal following cultural changes in the aftermath of World War II. The impact of the work of this ecumenical council is evident in a number of religious buildings in Australia. Our examples consider the application and value of some of the Fit for Sacred Use principles and suggested methodologies in practice. There are some big issues facing the whole church in relation to our heritage as expressed in architecture and art, as attendance continues to decline, parishes amalgamate, and property is considered for demolition, reuse or repurposing. It provides an opportunity to reflect on the importance of our places of worship in our faith communities.

This paper analyses five examples with this in mind: St Patrick's Cathedral in Melbourne where much heritage was lost in the 1970s and 1990s re-orderings; SS Peter and Paul Church at Bulimba, Queensland and St Francis Xavier Cathedral in Geraldton, Western Australia where new thinking is manifest and heritage is respected; Mary Immaculate Church in Ivanhoe (Melbourne) a modern church which, when no longer needed, was slated for demolition; and St Patrick's Cathedral in Parramatta, New South Wales, which brings the notion of existing and contemporary together.

\section{ST PATRICK'S CATHEDRAL, MELBOURNE}

St Patrick's, the cathedral church of the Archdiocese of Melbourne (Victoria, Australia), is a significant heritage-listed nineteenth-century building (VHR H0008; Victorian Heritage Register 1999) that was reordered in the 1970s and again in the 1990s (de Jong 2005; de Jong 2014) (Fig. 01). It provides an opportunity to reflect on the footprint left by the renewal of the Catholic liturgy after the Second Vatican Council. The practice of liturgy is a type of gestural system. In other words, liturgy is both a ritual and symbolic action that happens in a public setting. It therefore determines how, where and when to move and what gestures to carry out in order to bring each person into contact with the abstract concept of God. The gestural system binds ideology to practice, escaping from abstraction through, for example, making the sign of the cross or partaking in communion (Lefebvre 1991). In our case the gestural systems of Catholic liturgy connect the representation of space as conceived by the Church hierarchy with the representational space as lived by its community.

Richard Falkinger, architect of both re-orderings considers that while Vatican II was formative, it was not prescriptive in any sense (Falkinger 2002). The book And when churches are to be built reminds us that

the historical development of the liturgy was integral to the evolution of the spatial arrangement of churches, beginning from the fourth century. $(2015,16)$

When St Patrick's was re-ordered in the 1970s, the 19th century elements that both defined and represented the cathedral's physical and ritual heritage were cast away (Fig. 02). Yuncken Freeman Architects, through Roy Simpson and Richard Falkinger, designed a modern, purist, non-hierarchical space free from ornament. The sanctuary was brought forward into the main crossing of the traditional cruciform cathedral. Pulpit and altar rails were discarded. A timber platform was built, upon which a simple altar table and cathedra were constructed. The whole was carpeted. The transept pews were turned $90^{\circ}$ to face the new sanctuary (Falkinger 2002). Roy Simpson's philosophy is further exemplified in the new Diocesan offices and presbytery, built largely 

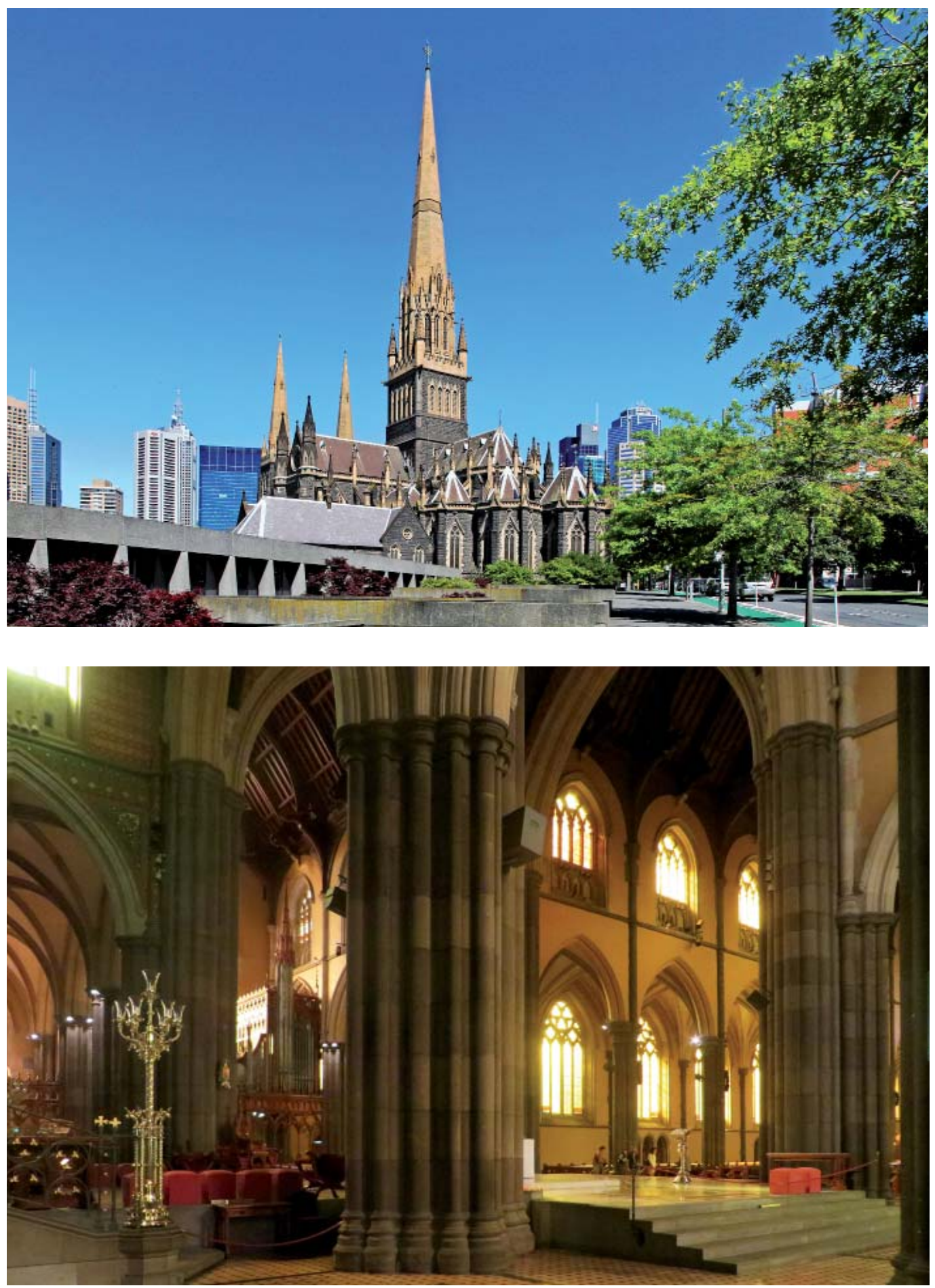

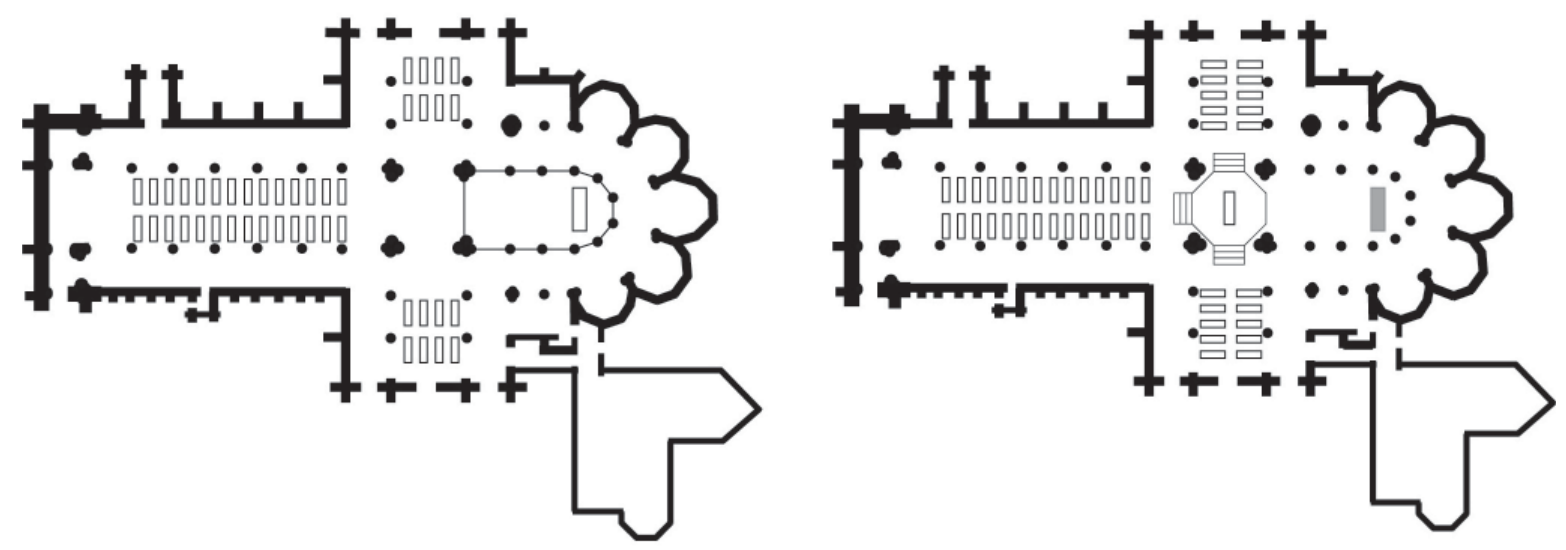

Left, page above. Fig. 01. William Wardell. St Patrick's Cathedral, Melbourne (Australia), 1858-97 (spire 1939); exterior view with Roy Simpson's diocesan offices in the foreground, 1970s.

This page above. Fig. 02. Schematic plans before (left) and after (after) the interior re-ordering.

Left page below. Fig. 03. Interior view of the 1990s reordering, showing position of the permanent sanctuary in the crossing of the cathedral.

underground adjacent to the Cathedral (Fig. 01). The celebration of the centenary of the cathedral's consecration and opening in 1997, called for these temporary changes to be made permanent. The 1990s reordering by Richard Falkinger and Arthur Andronas (Fig. 03) constructed a solid concrete sanctuary platform in the crossing and introduced a Celtic interpretation of the four gospel writers in the tiled sanctuary floor, valorising the largely Irish Catholic community who had built and paid for the nineteenth-century cathedral. A new carved marble altar was commissioned and installed (de Jong and Marcello 2017). The 1970s work was reversible, the 1990s is not. The Burra Charter, which defines the basic principles and procedures to be followed in the conservation of Australian heritage places

advocates a cautious approach to change: do as much as necessary to care for the place and to make it useable, but otherwise change it as little as possible so that its cultural significance is retained. (Australia ICOMOS 2013).

The implementation of Vatican II liturgical changes created huge problems for traditional churches such as Melbourne's St Patrick's Cathedral. How do you turn a longitudinal compartmentalised plan around to accommodate the notion of a more centralised plan to embrace the congregation and invite full and active participation by the assembly? How do you respect the heritage building, church traditions and history, and embrace the new? How do you recodify post-Vatican II rituals and gestures, when the physical objects defining space support pre-Vatican II gestures and ritual? Falkinger was

keenly aware of the difficulties in achieving the right balance between the need for the retention of our past and an honouring of the future - through the creation of a worthy and sacred place which truly reflects the needs and aspirations of the people of this age, who seek to celebrate the Liturgy of the Word and the Eucharist in today's language of belief. (Falkinger 2002)

The Scriptures also attest to the care that ought to be taken when bringing together the old and the new:

No one sews a piece of unshrunken cloth on an old cloak; otherwise, the patch pulls away from it, the new from the old, and the tear gets worse. And nobody puts new wine into old wineskins; otherwise, the wine will burst the skins, and the wine is lost and the skins too. (Mk 2,21-22; FFSU 784) 

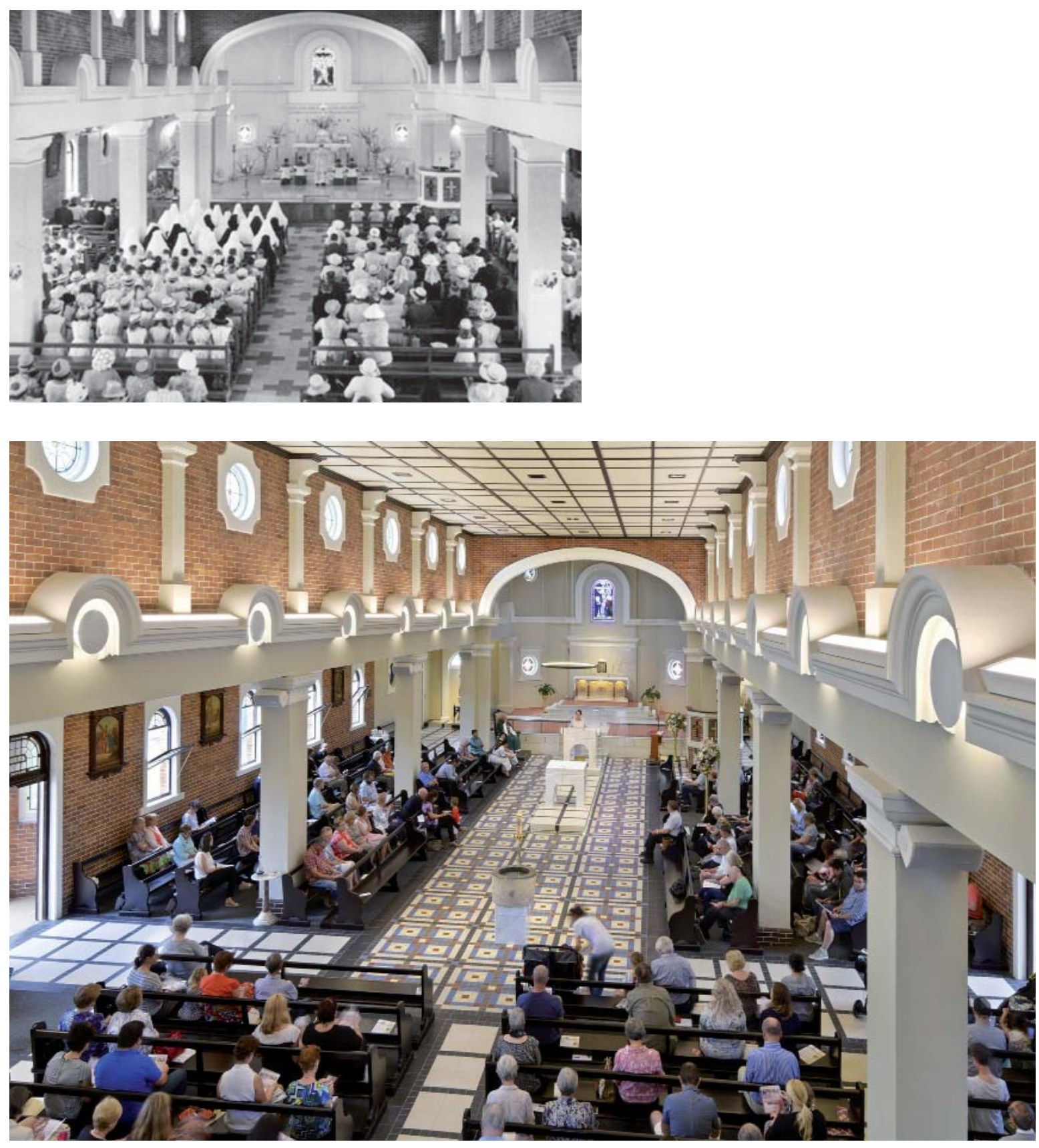

Fig. 04. Harry J. Marks. SS Peter and Paul, Bulimba-Brisbane (Australia), 1926. Worship according to the Tridentine model, a Latin Mass celebrated in a pre-Vatican II longitudinal church.

Fig. 05. Interior view of 2015 Dion Seminara Architecture reordering: note change in orientation of seating, relocation of altar, ambo and baptismal font. 
At St Patrick's Cathedral, twentieth-century liturgical directives clashed head on with a cathedral built for nineteenth-century liturgical practices, because the church building and what happens inside it are designed as an integrated whole. For the Vatican II requirements to be recognised and honoured, the heritage values of the nineteenth-century building were compromised. How we adapt and respect tradition raises questions about changing values and understandings of heritage and local/global interpretations. Understanding our culture, our history and the patrimony of the Catholic church are critical to valuing an evolving heritage. This is why NLAAC prepared guidelines for use throughout the Catholic Church in Australia.

\section{SS PETER AND PAUL CHURCH AT BULIMBA, QUEENSLAND}

SS Peter and Paul at Bulimba was designed as a Jeffersonian neoclassical building by Harry J. Marks and opened in 1926 (Fig. 04). The 2015 restoration and reordering of this parish church exemplifies some of the rethinking that has gone into capturing the understanding that the liturgy is offered by the whole Body of Christ, all the baptised (Fig. 05). A number of Fit for Sacred Use heritage principles underpin this work (FFSU 806, 807 and 809):

- The heritage of church architecture and liturgical objects articulates fundamental values of truth and beauty for all of humanity and these need to be researched, understood and valued when renewing places of worship (806).

- Church heritage represents the spiritual aspirations of human beings both in the past and present and is deserving of respect when change is being considered (807).

- Culture and heritage are not static but ever-evolving throughout human history. They attain value in service of human beings and the changing human communities in which they live (809).

The work at SS Peter and Paul at Bulimba was undertaken by Dion Seminara Architecture in partnership with the parish priest, and chair of the NLAAC, Dr Tom Ellich. Here the longitudinal emphasis of the basilica has been partially turned around to ritualistically reorganise the interior church space. The old sanctuary now is used as the Blessed Sacrament Chapel (Fig. 05). The space has been adapted and reordered to honour the new inclusive liturgy enabling full and active participation by all, while respecting the heritage of the church building.

\section{ST FRANCIS XAVIER CATHEDRAL IN GERALDTON, WESTERN AUSTRALIA}

One of Australia's most distinctive cathedrals, St Francis Xavier Cathedral in Geraldton, Western Australia was designed by John Cyril Hawes in 191618 (Fig. 06) (Taylor 2000).

A $\$ 9$ million project to conserve and enhance the heritage-listed ecclesiastical building and its precinct, including a major conservation program, the development of a Hawes interpretative centre and piazza, a cathedral forecourt and a wildflower garden, opened in 2018 (Fig. 07). As noted in Fit for Sacred Use

in regards to its social significance, the art-historical patrimony serves as a peculiar instrument of aggregation. It is a source of civilisation because it promotes the process of transformation of the environment at a human scale, it maintains the memory of the past within each generation, and offers the possibility of transmitting its own works to posterity».(FFSU 804; PCC 5, 3.1)

John Taylor Architect was the architect for the restoration, conservation and enhancement of St Francis Xavier Cathedral in Geraldton. He worked closely with Fr Robert Cross, Chancellor and Director of Heritage, Diocese of Geraldton, Western Australia and NLAAC member. Honouring heritage was fundamental to their work because

places of cultural significance enrich people's lives, often providing a deep and inspirational sense of connection to community and landscape, to the past and to lived experiences. (Australia ICOMOS 2013, preamble)

Nowhere is this more clearly evident than in Catholic communities and their churches (FFSU 1271). As well, this project especially recognised that renewing a church to be fit for sacred use is complex. It demands an understanding and application 

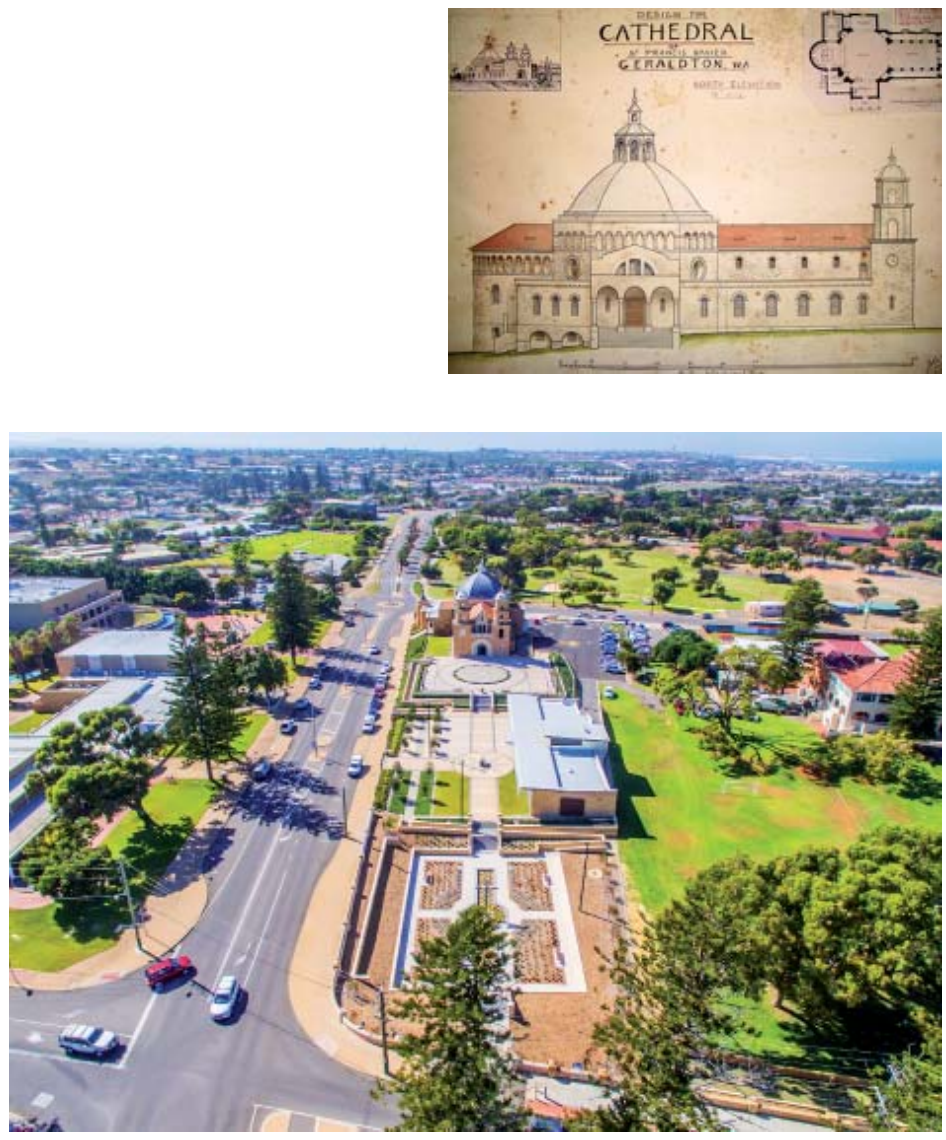

Fig. 06. John Cyril Hawes. St Francis Xavier Cathedral, Geraldton (Australia), 1916-18. Fig. 07. Overview of John Taylor Architect's work on the ecclesiastical building and its precinct, opened in 2018.

Fig. 08. Interior reordering by John Taylor Architect, opened in 2018.

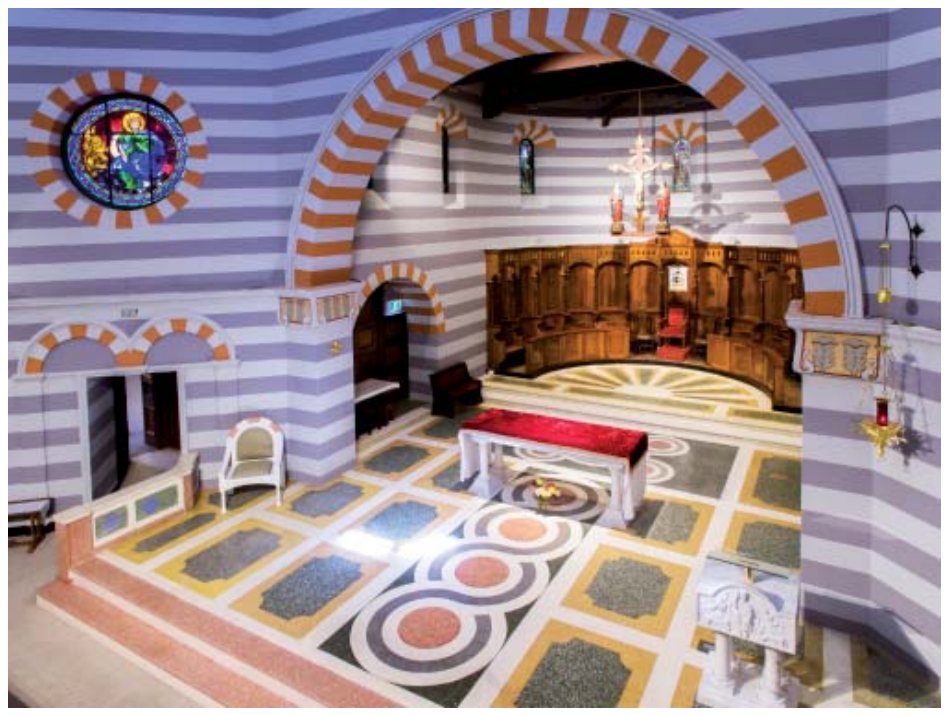


of both civic and church heritage principles and processes. Community consultation will be needed to discern and articulate what is valued and treasured. It involves the participation of historians, archivists, architects with heritage expertise, liturgists, conservators, archaeologists, artists and craftspeople. It necessitates the development of a conservation plan and the creation of an inventory-catalogue. (FFSU 1272)

The Burra Charter principles underpinned the work philosophically and practically. Appreciation of both liturgy and heritage is manifest in the reordering of the interior space (Fig. 08). The sanctuary has been sensitively moved forward, with free standing altar and ambo. The cathedra has been centred in the old sanctuary, with furnishings preserved and rood cross with figures restored. This reordering honours Vatican II liturgical requirements, invites the assembly's participation and fosters both dignity and respect among the building's users for the heritage structure.

The reordering adaptations of these examples of existing churches in response to Vatican II show three manifestations of how Fit for Sacred Use has been interpreted: in Melbourne the permanent reordering destroyed the central crossing of the heritage Cathedral; in Brisbane the longitudinal church space was partially horizontally reoriented; in Geraldton, restoration and conservation of the Cathedral were undertaken at the same time as adapting it to the new liturgy. In designing new churches the new liturgical principles were much easier to anticipate and apply. The next example raises issues in circumstances where the congregation has dwindled and modern heritage is not appreciated.

\section{IVANHOE - A MODERN CHURCH}

The Mary Immaculate Church (1960-62) was designed by the Melbourne-based architectural practice Mockridge Stahle \& Mitchell, a prominent architectural firm established in Melbourne in 1948, particularly well-known for its designs for churches, school and university buildings (VHR H2188; Victorian Heritage Register 2010 and 2019). Its partner John Mockridge was largely responsible for St Mary's design and detailing (Fig. 09-10).
The church was designed to accommodate a congregation of 450 with extra room in the Ladye Chapel and the narthex, and built to a total cost of $£ 49,000$. The fan-shaped plan — anticipating Vatican II's mandate to encourage full, conscious and active participation - was designed so that every worshipper has a clear view of the altar (Fig. 10).

The building has dark-grey rock-faced walls and a terra-cotta cordova tile roof. The almost $30 \mathrm{~m}$. steel-framed spire was sheeted in copper and floodlit at night (Fig. 09). A 1961 article proclaimed:

The central altar will be flooded with light from six Perspex domes directed though a canopy over the altar, and a decorative screen will form a dramatic backboard to the sanctuary. (Today's News 1961, 9).

In response to the conclusion of the second Vatican Council, an adjustment was made to the glass panelling at the back of the sanctuary so that the altar could be moved forwards and the priest could celebrate Mass facing the people. No other spatial reordering was required as the church plan anticipated the coming changes flagged by liturgical renewal.

Today St Mary Immaculate is one of three churches in the Ivanhoe parish. It is no longer an active church and has been considered for demolition. Architectural consultant Rohan Storey (2017) considers St Mary Immaculate a spectacular example of a modern church, with a landmark pointed copper spire, soaring portal framed, trapezoidal planned interior, and extensive coloured glass windows and integral art works (Fig. 12). While it is considered to be of historic, architectural, aesthetic, social and spiritual significance to the City of Banyule, this church has no heritage protection at State or local level. In July 2018, the Church of Mary Immaculate hit the news with headlines reading:

Catholic Parish of Ivanhoe denies plans to rezone and sell off modernist church amid calls for it to be protected. (Sadler 2018)

An assessment made in October 2017 stated that the intactness of the church is good and the integrity of the church is very good. In July 2018, the National Trust of Australia (Victoria) recommended that the City of Banyule consider an amendment to 

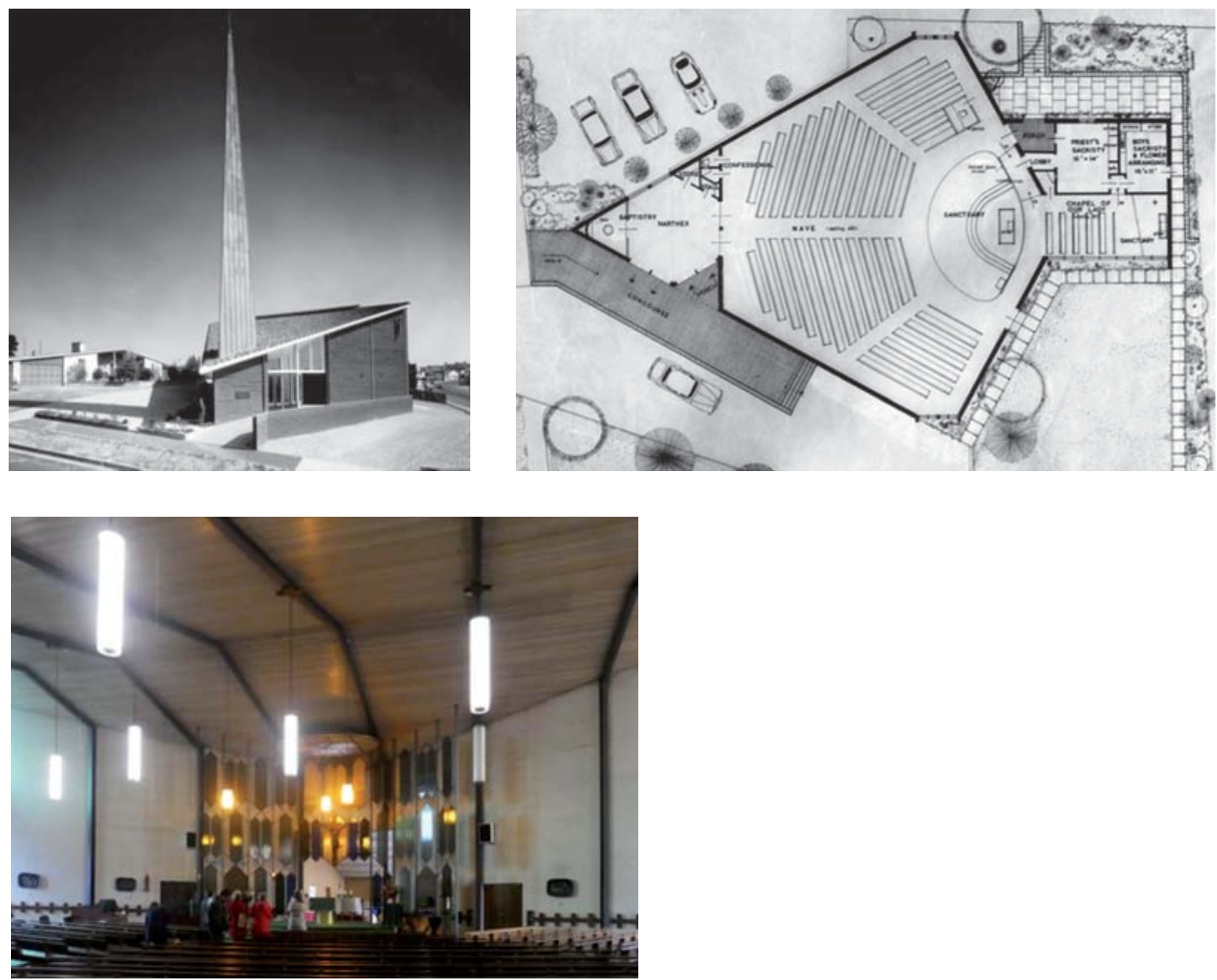

Fig. 09. John Mockridge (Mockridge Stahle \& Mitchell). Mary Immaculate Church, Ivanhoe (Australia), 1960-62; exterior view not long after opening.

Fig. 10. Original plan.

Fig. 11. Interior view of fan shaped plan, looking towards sanctuary.

Fig. 12. Interior view of the Ladye Chapel, original altar, statue and glass. Unsympathetic altar table and furnishings.

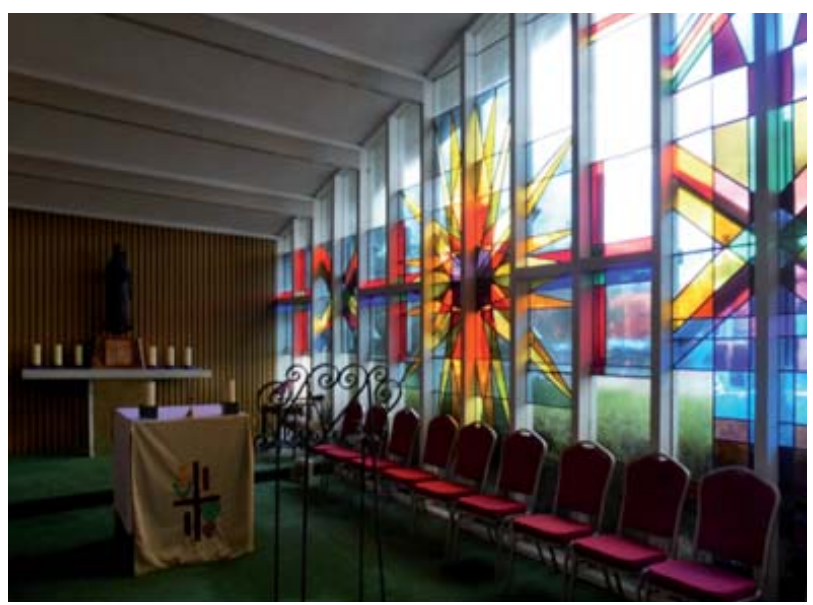


their Planning Scheme to provide protection for this church, after the Heritage Council of Victoria found that the building did not reach the threshold for inclusion in the Victorian Heritage Register (Heritage Council 2017; Australia ICOMOS 2013). In this case many heritage values came into play, as well as many interests. Fit for Sacred Use makes it clear that «the cultural heritage of a church grows from the lived tradition of the community. It concerns not just a building and its curtilage (its physical setting or surroundings) but also peoples' customs and practices, artistic expressions and values, meanings and attachments» (FFSU 1274). Heritage is holistic, encompassing natural and cultural significance, tangible and intangible aspects. The community here includes the parish and the archdiocese, the neighbours, the wider local community, architects, artists and designers, heritage professionals and architectural historians. This church is ensconced in a faith community and it also makes a significant contribution to the civic space. It is a local landmark and articulates a corner through its presence as an exceptional artistic building. Mary Immaculate Church has significance for all and is valued by each depending on their perspective, because «cultural heritage speaks about place, history, identity and memory» (FFSU 1276).

In this context Fit for Sacred Use notes that as well as

the foundational liturgical principles, there are heritage principles which come into play when considering the stewardship and renewal of places of worship. Both church and civic heritage documents recognise cultural heritage to have aesthetic, historic, scientific, social and spiritual values. Heritage addresses the human search for meaning, and also personal and group identity and memory

but it makes it plain that

the Church's discernment of the significance of works of sacred architecture and art created to serve the liturgy has a particular focus».(FFSU 792)

Fit for Sacred Use continues that

while the typology of cultural goods is analogous to that defined by civic state legislation, the perspective through which they are seen by the Church is above all religious. The cultural goods of the Church are an expression of the life of faith of the Christian community, they are placed at the service of the mission of the Church, and so are judged by the measure of Christ. They are appraised in the context of the liturgical life, the piety and charity for which they were created. Works of art and architecture from the past need to be kept and conserved with great care because they are a witness to the tradition of the believing people of God; this stewardship continues even when their specific use has finished. (FFSU 793)

While St Mary Immaculate is not a current container for ritual, it embodies important aspects of intangible heritage within the many ritual practices that occurred there in the past. It is also a significant piece of modern architecture. Civic concerns in relation to the heritage values of St Mary Immaculate in Ivanhoe have meant that the parish is now reconsidering the use of this church building, at the same time as the local government authority is considering whether to apply a local heritage overlay to the church and its precinct, in order to protect it.

\section{ST PATRICK'S CATHEDRAL PARRAMATTA NSW}

St Patrick's Cathedral in Parramatta is a fine example bringing together heritage and contemporary concerns in the design of new Cathedral (Fig. 13). Romaldo Giurgola was commissioned to design a new cathedral for Parramatta after the historic building (begun in 1857) was destroyed by fire. The new complex, which opened in 2003, incorporates the site's history, memory and fabric. The remaining shell of the historic church was turned around, redesigned and repurposed as the Blessed Sacrament Chapel, the baptistery and the main entrance to the new cathedral (Fig. 15). The people's seats in the new cathedral space are arranged in tiers so that, gathered either side of the altar and ambo, the assembly is celebrant of the liturgy (Fig. 16).

In Luminous Simplicity. St Patrick's Cathedral, Parramatta the architect Giurgola asked Australians to «bear in mind that architecture remains a symbolic expression of people's cultural identities and aspirations in all facets of life» (Giurgola 2007, 27). 


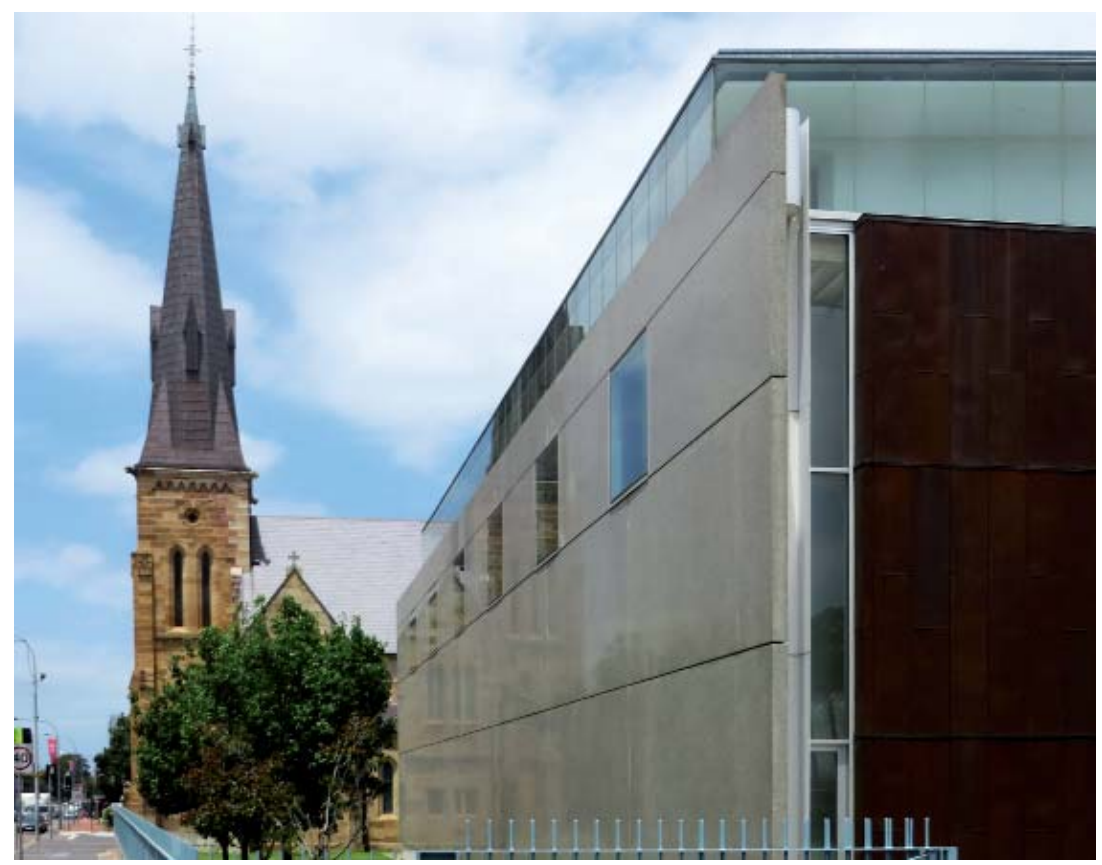

Fig. 13. Romaldo Giurgola et al. St Patrick's Cathedral, Parramatta (Australia), 1997-2003; exterior view of rebuilt original building dating from 1857 and the new cathedral in the foreground, opened in 2003. Fig. 14. Schematic plan, repurposed historic building on the right, provides entry to the new cathedral space on the left.

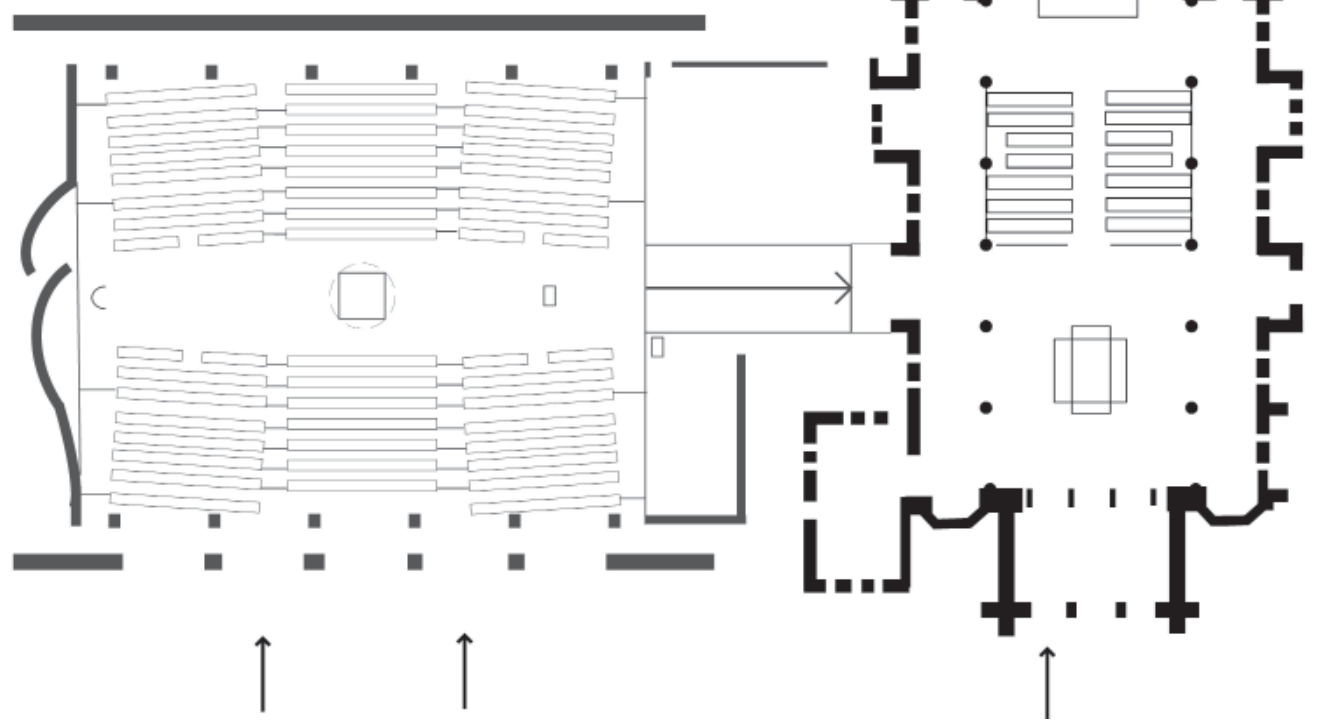



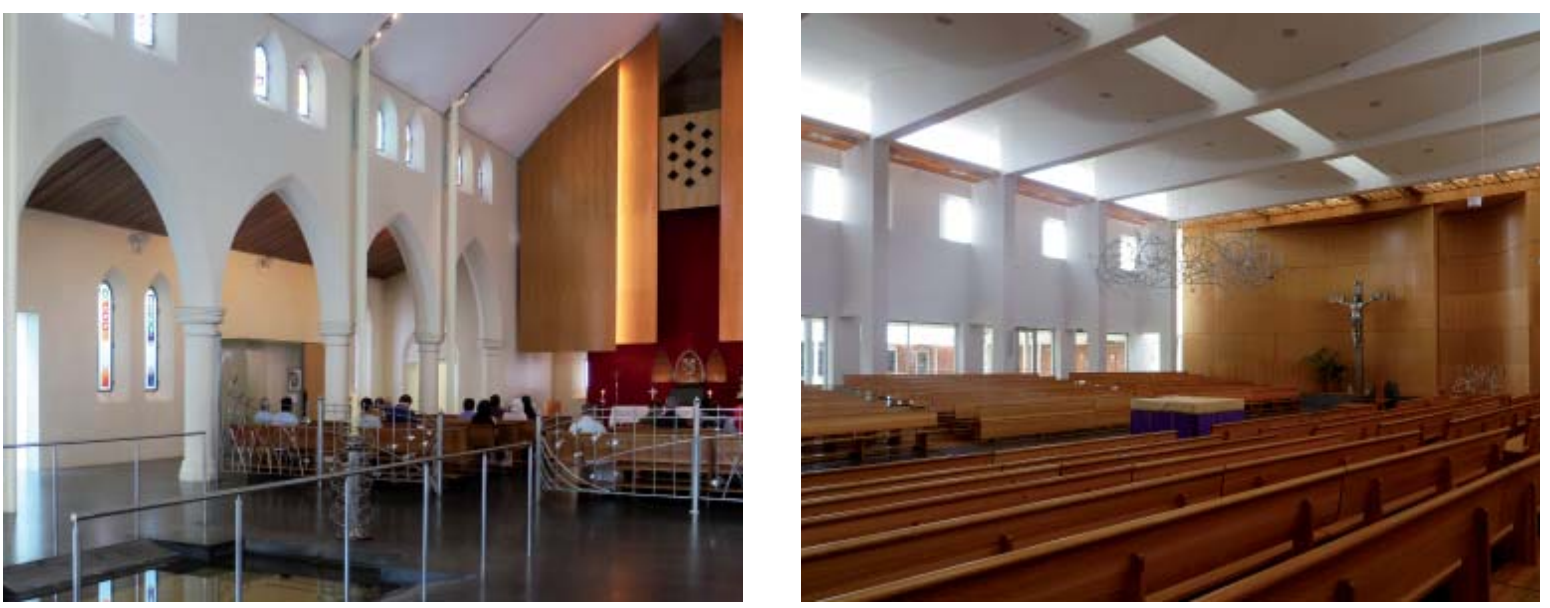

Fig. 15. Romaldo Giurgola et al. St Patrick's Cathedral, Parramatta (Australia), 1997-2003; interior view of rebuilt and repurposed original building dating from 1857, now Cathedral entry, baptistry and Blessed Sacrament Chapel. Fig. 16. Interior view of new cathedral featuring a light-filled open space, with seats facing the centrally located altar, ambo and cathedra.

As Fit for Sacred Use expresses, the cultural heritage of the church communicates Christian values through the «relationship between human culture and the work of God the Creator» seen in the biblical image of Wisdom

I was by (God's) side, a master craftsman, delighting him day after day, ever at play in his presence, at play everywhere in his world, delighting to be with (human beings). (Prov 8,30-31; FFSU 816).

At Parramatta, artists and craftsmen worked alongside the architects to honour heritage and the living tradition of the Catholic church in Australia. Great care was taken

to enlighten and direct the minds and hearts of the artists to whom is given the task today of restoring or rebuilding the many churches which have been ruined or completely destroyed. (MD 196; FFSU 81)

through the inventive solution of reordering and restoring the old church and adding the new cathedral at right angles to it. This also demonstrates how «the Church is committed to maintain the original function of her art-historical patrimony» (FFSU
821). Giurgola also reflects on the creation of a new Cathedral and the importance of the integration of all the arts in its realisation. Giurgola considers that «architecture remains as abstraction until daylight, materials, colour, art, and people give it substance» (2007, 28). At St Patrick's, architecture synthesises all components of the liturgical environment: the gathering community; the altar; the table of the word; the presidential chair; the Baptistry; the tabernacle; the Easter candle; the holy oils; the place of reconciliation. Stained glass, drawing, sculpture, craftsmanship in furnishings and metal work contribute to a whole symphony of creation. Giurgola makes clear that

Only a thoughtful consideration of the building's content gives to architecture a concrete manifestation of its historical position in time; it establishes its character and eventually its form, its relevancy, and above all its sense of limit in its role and making. $(2007,29)$

St Patrick's demonstrates a creative narrative in realising, in Giurgola's words, «a sublime narrative of spiritual life» (Giurgola 2007, 37). 


\section{CONCLUSION}

The guidelines Fit for Sacred Use recognise that the cultural heritage of the church communicates Christian values through liturgical and heritage principles. The way human beings express their encounter with truth, beauty and goodness varies from culture to culture and across time (FFSU 822). When we refurbish a church we need to value, respect and celebrate this richness of cultural diversity. Two principles are key - participation and stewardship:

- When a place of worship is to be renewed or repurposed, the local church community is to be genuinely consulted and engaged in the whole process (FFSU 823).

- Good stewardship of places of worship demands that professionals be engaged to assess the existing architecture, art, sacred furnishings, spaces and views of the place for their aesthetic, historic, scientific, social and spiritual significance. Where these are of high significance, they should be valued and respected (FFSU 824).

The examples discussed in this paper provide different responses to Vatican II across time. The 1970s and 1990s re-orderings at St Patrick's Cathedral Melbourne bring the relationships between heritage, church traditions and new liturgical understandings sharply into focus. The nineteenth-century Gothic Revival architecture did not lend itself well to post Vatican II liturgical requirements and the interventions have compromised both the building's tangible and intangible heritage. Nineteenth ${ }^{-}$century fittings and furnishings have been lost. More than half a century after Vatican II, we have a clearer understanding and a more refined appreciation of the architectural requirements of the Order of Mass and the other rites of the Church. During this same period, our society and the Church have also grown in awareness of the heritage significance of our church buildings and of the sacred art that adorns them (FFSU, Foreword). Brisbane, Geraldton and Parramatta show how this can be done sensitively in quite different ways. Notions of the sacred, of community, of belonging and of place are at the heart of the design briefs for all of these projects. Ivanhoe (Melbourne) challenges faith communities to appreciate modern heritage and to come up with creative adaptive solutions to real problems facing the church today. The guidelines, grounded in liturgical and heritage principles, offered in Fit for Sacred Use will play a key role in inspiring change, leading transformations of ideas, form and concepts in sacred and everyday realities, and in encouraging emerging and unfolding creative explorations and experimentations in Australian sacred spaces and religious buildings.

\section{BIBLIOGRAPHY}

«Today’s News». 1961. Architecture Today [February]: 9.

Australia ICOMOS. 2013. The Burra Charter: The Australia ICOMOS Charter for Places of Cultural Significance. Accessed 10/01/2019, http://bit.ly/2ZHVF9e.

Australian Catholic Bishops Conference. 2015. And when churches are to be built... Preparation, planning and construction of places for worship. Brisbane: Liturgy Brisbane

Australian Catholic Bishops Conference. 2018. Fit for Sacred Use: Stewardship and Renewal of Places of Worship [FFSU]. Brisbane: Liturgy Brisbane.

De Jong Ursula and Flavia Marcello. 2017. «'Fitted for sacred use': Vatican II and Modernism in the physical, social and ritual space of three Australian churches», paper presented at the 34st Annual Conference of the Society of Architectural Historians, Australia and New Zealand (SAHANZ), Camberra (Australia).

De Jong, Ursula and Flavia Marcello. 2018. «Shaping Australian Catholic Communities: Built Responses to Modernism, Population Growth and Changing Liturgical Practices Before and After Vatican II», paper presented at the symposium «Constructing religious territories. Community, identity and agency in Australia's modern religious architecture», organised by Philip Goad and Lisa Daunt. The University of Melbourne.

De Jong, Ursula. 2005. St Patrick's Cathedral, Melbourne - a Guide. Melbourne: Catholic Archdiocese of Melbourne. 
De Jong, Ursula. 2014. «Translating the Gothic tradition: St Patrick's Cathedral Melbourne», paper presented at the 31st Annual Conference of the Society of Architectural Historians, Australia and New Zealand (SAHANZ), Auckland (New Zealand).

Falkinger, Richard. 2002. Ringing the changes: new liturgy versus heritage: chronicles 1971-2000. Ringwood: David Lovell.

Giurgola, Romaldo. 2007. Luminous Simplicity: The Architecture and Art of St. Patrick's Cathedral, Parramatta: Macmillan Art Publishing.

Heritage Council. 2017. «Recommendation of the Executive Director and assessment of cultural heritage significance under Division 3 of the Heritage Act 2017» [Mary Immaculate Church]. Accessed 10/01/2019, http://bit.ly/2rMYQji.

Lefebvre, Henri. 1991. The production of space. Oxford: Basil Blackwell.

PCC 5/Pontifical Commission for the Cultural Heritage of the Church. 2000. «The Inventory and Catalogue of the Cultural Heritage of the Church». Accessed 22/07/2019, http://bit.ly/39xAhIj.

Sadler, Denham. 2018. "Catholic parish of Ivanhoe denies plans to rezone and sell off modernist church amid calls for it to be protected», Commercial Real Estate, 18 July. Accessed 10/01/2019, http://bit.ly/2Qeyclh.

Storey, Rohan. 2017. The Modernist Heritage Conundrum. Accessed 10/01/2019, http://bit.ly/2rNzZMi.
Taylor, John. 2000. Between Devotion and Design: The Architecture of John Cyril Hawes 1876-1956. Nedlands: University of Western Australia Press.

Vatican II. 1963. Sacrosanctum Concilium. Constitution on the Sacred Liturgy. Accessed 26/09/2019. https://bit.ly/IshIHU.

Victorian Heritage Register. 1999. «St Patrick’s Cathedral Precinct (VHR H0008)». Accessed 22/07/2019, http://bit.ly/39yH1Wa.

Victorian Heritage Register. 2010. «St Faith's Anglican Church (VHR H2188)». Accessed 22/07/2019, http://bit.ly/2SXofSP.

Victorian Heritage Register. 2019. «Religious Centre Monash University». Accessed 22/07/2019, http://bit.ly/2MNKpD5.

\section{SOURCE OF IMAGES}

Fig. 01, 03, 11-13, 15-16. Ursula de Jong.

Fig. 02, 14. Flavia Marcello.

Fig. 04. www.bulimbacatholic.com.

Fig. 05. Courtesy of Bulimba Parish and Dion Seminara, architect.

Fig. 06. Monsignor Hawes Heritage Centre Fig. 07. Photograph, copyright The Roman Catholic Bishop of Geraldton.

Fig. 08. Debra Mitchell (Photograph Owner), copyright The Roman Catholic Bishop of Geraldton.

Fig. 09. Wolfgang Sievers.

Fig. 10. https://catholic-parish-ivanhoe.webs.com, 